\title{
Tyrosine-Protein Kinase Blk
}

National Cancer Institute

\section{Source}

National Cancer Institute. Tyrosine-Protein Kinase BIk. NCI Thesaurus. Code C17697.

Tyrosine-protein kinase Blk (505 aa, $~ 58$ kDa) is encoded by the human BLK gene. This protein is involved in protein phosphorylation and B-cell receptor signaling. 